\title{
Baseline Study About Discipline Practice In Schools Papua And West Papua Province
}

\author{
$1^{\text {st }}$ Nursalim $^{1}, 2^{\text {nd }}$ Surya Putra Raharja ${ }^{2}$ \\ \{nursalim@unimudasorong.ac.id ${ }^{1}$, suryaputraraharja@gmail.com² \\ Teacher Training and Education Faculty Universitas Pendidikan Muhammadiyah Sorong, West Papua, \\ Indonesia
}

\begin{abstract}
Study baseline on discipline practice in school conducted as a strengthening reading and writing education in pre-school students in the edged and isolated area in Papua and west Papua province. The improving quality result of reading and writing that students achieved is not only through teachers skills improvement in teaching reading and writing, but also by creating school environment which is save and free from children abused. The aimed of study baseline is to give discipline practice that applied by teachers in school. And also about teachers and students viewed about punishment. The sample data consisted of teachers, headmasters, and students. Teachers and headmasters as the practitioners who used the punishment to control the students' behavior. Students as the important elements in this study because they were the ones who felt the impact of giving punishments to create disciplinary in school. The pre-school teachers who involved in this study. The students who involved as repondents in this study was the students in first grade until third grade. One-third students of the total students who was presented when this study conducted was chosen as the respondents. The selected schools were 6 schools from 20 basic literacy schools model program in Biak Numfor regency, Jayawijaya, Manokwari, and Mimika. Data collection was done by researched and interviewed to the teachers and headmasters was conducted by Focus Group Discussion (FGD), and the students was done by asking teachnique 'find out'. Study results showed that teachers still wrong in interpreting discipline and equated as punishment. Teachers responded on students' negative behavior (Misbehave) in hard ways, embarrassing, and harassing. Teachers continuesly became angry/ punished the students even only for little mistakes.
\end{abstract}

Keyword: Discipline practice, teachers, students

\section{Introduction}

United nations convention about children rights that every kinds of a violence never justified. But in the fact violence become primary challange in the protection of children. The violence subject can be parents, sibling, family, teachers, and the children itself. Study consultation on children in 18 provinces in Indonesia showed that the violence in children daily life (Arna, 2005). Physical punishment, for example mostly in family and school environment used the punisment for discipline the children. In school they believed that physical punishment is able to control the students and able to make the students may learn better. Physical punishment considered as effficient way to teach the students to have a good behave and make them study harder. 
Physical punishment is forbidden in many countries. In Indonesia, government released law number. 232002 (then changed become law number 35 2014) to guarantee the children rights and they may lived, grew, and developed in maximum and also protected by the kinds of violence But until now, the violence in chidren education in Indonesia still happening. Physical punishment practice still become long debate. There are many parents and educators who still support the idom 'Di Ujung Rotan Ada Emas' or it can be said giving punishment will bring benefit for students and it justified the use of violence in educating children/students.

The Study which conducted by UNICEF togather with statistic center in Papua and West Papua province showed that in Papua land, $93 \%$ chilren age 2-14 years old ever experienced violence at least one kind of physical violence or psychology that done by their mother or member of family. $30 \%$ received heavy violence ${ }^{1}$. KAP studied about the violence on woman and children was conducted by UN Joint Programm in the year of 2011 in Papua province showed that most of headmasters, teachers and students believed that physical punishments was a right way to discipline the students. Even teachers and parents believed that if did not use violence then the children will not obey to the teachers and parents ${ }^{2}$.

\section{Data Sample}

Data sample consisted of teachers, headmasters, and students. Teachers and headmasters as a practicioner who used punishment to control their students behavior. The students become the important element who get the impact from punishment practice to discipline the students. Teachers who involved in this study is pre-school teacher. And the students who involved as the respondents are first grade until third grade. One- third students from the total who presented during this study start will selected as respondents.

Table 1. Responden

\begin{tabular}{|c|c|c|c|c|}
\hline \multirow{2}{*}{ Name of Regency } & \multicolumn{2}{|c|}{ Total of teachers } & \multicolumn{2}{|c|}{ Total of students } \\
\hline & Man & woman & man & woman \\
\hline Biak Numfor & 10 & 13 & 31 & 31 \\
\hline Jayawijaya & 11 & 10 & 30 & 33 \\
\hline Manokwari & 6 & 13 & 56 & 56 \\
\hline Mimika & 6 & 18 & 53 & 55 \\
\hline \multirow{2}{*}{ Total } & 33 & 54 & 170 & 175 \\
\hline & \multicolumn{2}{|c|}{87} & \multicolumn{2}{|c|}{345} \\
\hline
\end{tabular}

The selected schools were six basic literacy schools model program in Biak Numfor, Jayawijaya, Manokwari, and Mimika Regency.

Tabel 2. Regency

\begin{tabular}{|c|c|c|c|c|c|}
\hline \multirow[b]{2}{*}{ Biak Numfor } & \multicolumn{4}{|c|}{ Regency } & \multirow[b]{2}{*}{ Mimika } \\
\hline & & Jayau & ijaya & Manokwari & \\
\hline SD YPK Mnurwar & SD & YPPK & Waga-Waga & SD Inpres 57 Meniy & SD Negeri 1 Pomako \\
\hline SD Negeri Sesur & SD & YPPK Y & wika & SD Inpres 45 Masni & SD YPPK Kaugapu \\
\hline
\end{tabular}

\footnotetext{
${ }^{1}$ Multiple Indicator Cluster Studi (MICS) 2011

${ }^{2}$ Multiple Indicator Cluster Studi (MICS) 2011
} 


\begin{tabular}{llll}
\hline SD YPK Dwar & SD YPPK Miligatnem & SD Inpres 85 Kaironi & SD Inpres Timika XIII \\
\hline SD Negeri Wodu & SD Inpres Kulagaima & SD Inpres 115 Waramui & SD YPPK Tipuka \\
\hline SD YPK Wounabraidi & SD Inpres Isaima & SD Inpres 107 Saubeba & SD Inpres Timika XII \\
\hline SD YPK Nusi & SD YPPGI Napua & SD Inpres 92 Warbefor & SD Inpres Timika IX \\
\hline
\end{tabular}

\section{Data Collection Method}

Data collection was conducted through study and interviewed to the headmasters, teachers, and students in multiple choice questioner. And interviewed in Focus Group Discussion (FGD) way to the headmasters and teachers. Meanwhile to the students used asking technique 'To Find Out'.

The questioners for the teachers and headmasters are consisted of 14 questions. Questioners designed to answer questions about kinds of students negative behavior (Misbehave), kinds of punishments which given by the teachers when punished the students, part of body that being the object of punishment, the impact of punishment on students' attendency, and also teachers and students perception on punishment.

Data collection conducted in two steps. The first step was conducted on 13-30 march 2019 and it focused on headmasters and teachers. The second step was conducted on 3 April 2019 until 13 Mey 2019.

To minimalized a bias and also to avoid the suspicious and rejection on sensitive topic in this study, then the respondents should be informed that this study will not mentioned their name and all the answered become confidentially guaranteed. Every respondents should signed Informed Consent as statements to be a respondent.

\section{Result and Discussion}

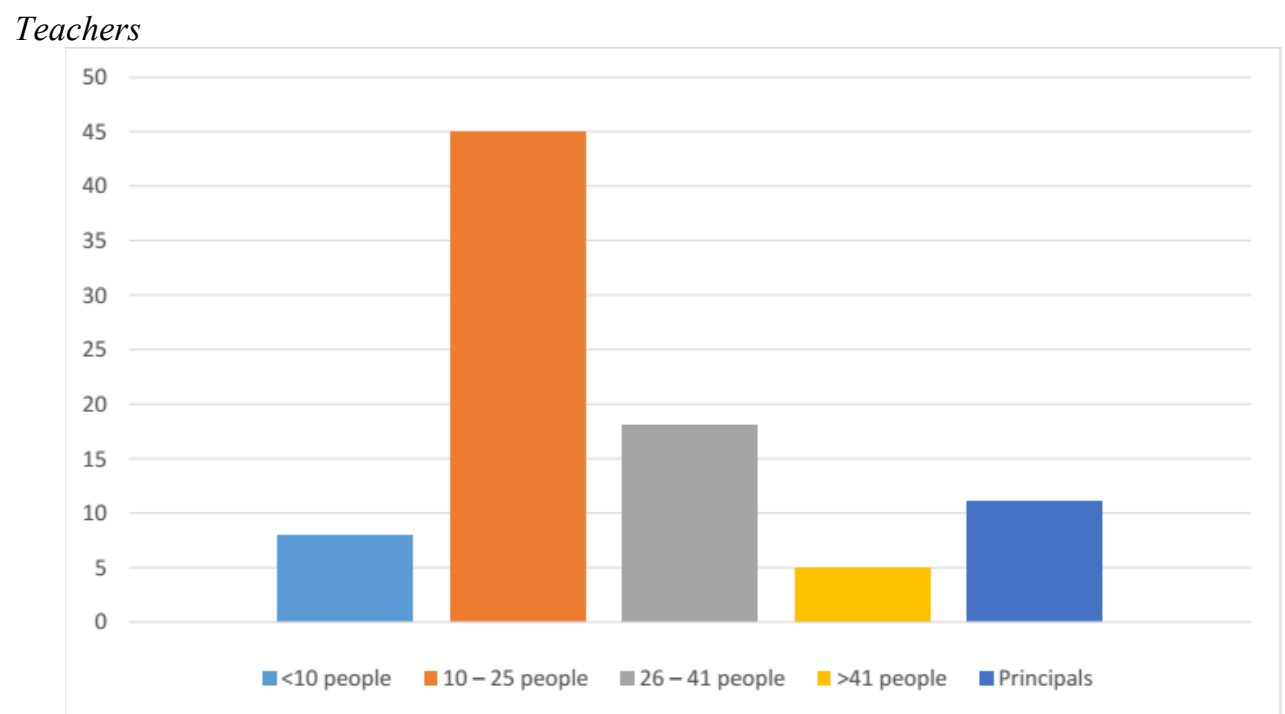

Figure 1. How many students in your class? 
From 87 resopondents of teachers and headmasters, 51,7\% teachers were teaching in class 'Medium' with the total students among 10-25 people, 20,7\% teachers were teaching in class 'large' with the total students among 26-41 people, 9.2\% teachers were teaching in class 'Small' with the total students did not more than 10 students. And 5.7\% teacher were teaching in class 'very large' with the total is more than 41 students . 11 headmasters $(12,6 \%)$ did not work as teacher.

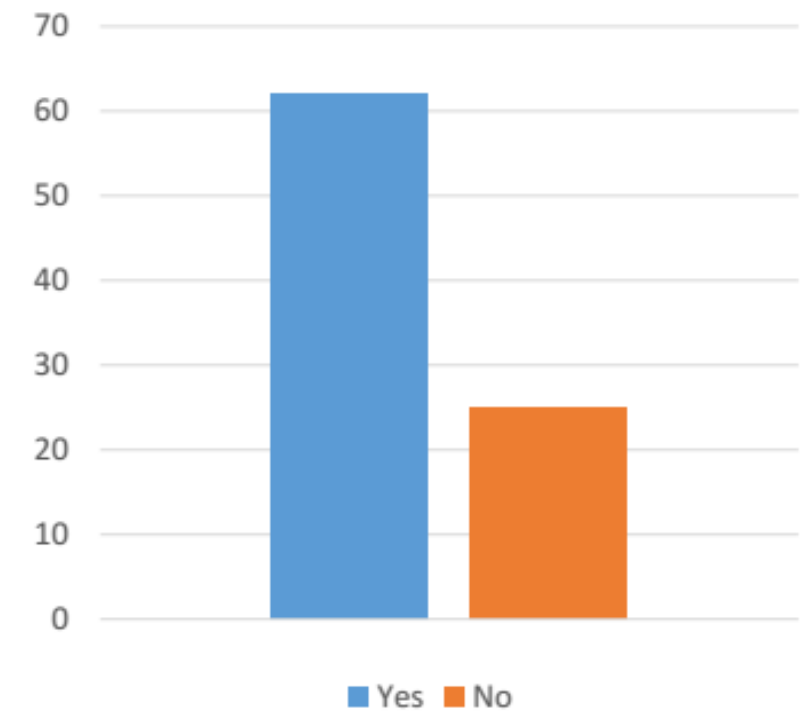

Figure 2. Does a disciplne as a problem in this school?

60

50

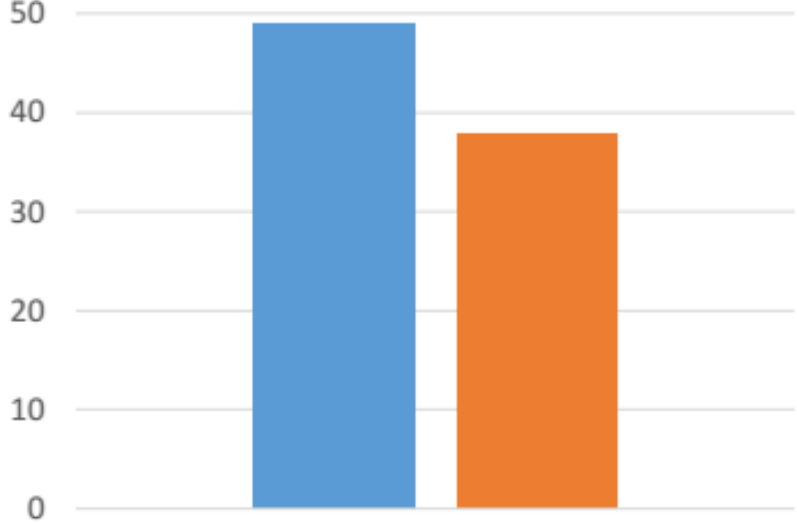

$\square$ Yes $\square$ No

Figure 3. Does Punishment occur in this school? 
$71.3 \%$ of Teachers said that they found difficulty in doing discipline practice to the students. $56.3 \%$ of Teachers admitted that used punishments to disciplne the students.

'Students entered and exited from the class without permission. Even teachers already remind them many times. They were adviced or being punished the result were same. 'Said teacher in Manokwari

'Students did not want to write. The reason was tired. And when they did not want to do it there is no way to asking more. Even a warn was nothing for them. The children characters here will never obey when the teacher did not tough. 'Said teacher in Mimika

'Children considered punishment and beating were familiar habit. So they won't waried' said teacher In Jayawijaya

'Children used to distrub their friends and $i$ already changed their chairs to the front but they still back to behind seat and distrubed their friends again' Said teacher in Biak

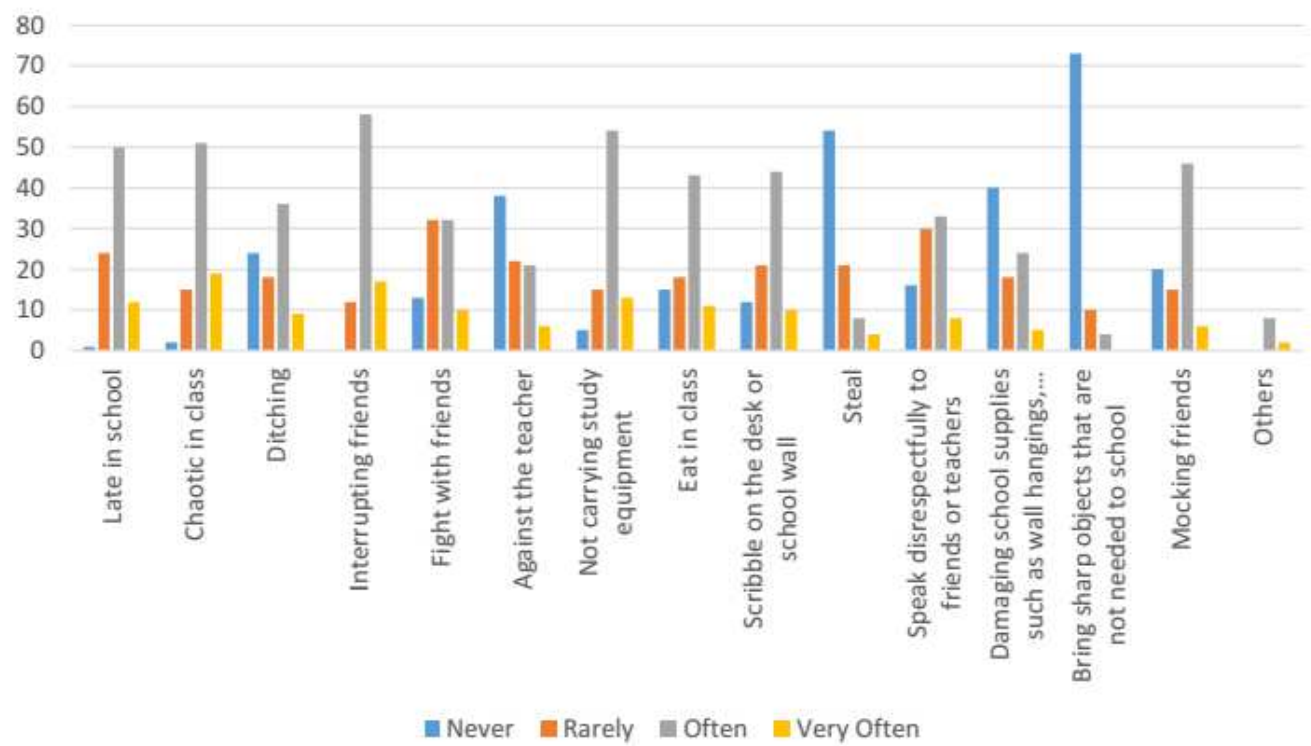

Figure 4. The kinds of Misbehave and undiscipline is familiar conducted by the students

Explanation:

Never: 0

Rarely: $1-2$ times in a month

Often: $1-2$ times in a week

Very Often: everyday/3 -6 times in week

Kinds of Misbehave that often conducted by the students were distrubed their friends $(67 \%)$, did not bring education stuffs like books and etc $(62 \%)$, noised in class $(58 \%)$ and late for school $(57 \%)$.

'In the beginning the students was only talking, then distrubing each others and then fighting. ' Said teacher in Jayawijaya

'Students were often did not bring education stuffs like books, pen, etc. Sometimes $i$ asked them to borrow the stuffs to their friends, and $i$ also punished them beacause $i$ 
was bored to see it happened again and again' Said teacher in Manokwari

'Students were easy to bored in study. Then made some noise in class. There should be something they fight for: like fight over something, distrubed each others.... 'Said teacher in Mimika

students often late for school because their parents did not care about it. Even there was a parent who like their children did not go to school because they were able to being requested to help them 'Said teacher in Biak

Kinds of the other Misbehave is the students used to mock and laugh to their friends who made mistakes (53\%). The mock was about physic insulted (ugly face, limp legs, big eyes, and the other), (53\%). And also insulting on their friends inability (the one who did not have shoes, torn clothes).

Students who used to skip the class (41\%), but $74 \%$ of teachers said there was no students who skipped the class because worried about punishment.

'Students did not attend the class because requested by their parents to go to field, to vilage, or to city' Said teachers in Jayawijaya and Mimika

'Students were going to school, but they were hurry to back home because of hungry and won't back to school again.' Said teacher in Manokwari

Students did unpolite talk to their friends (38\%) mostly they used rude words like animal. The other misbehave were imitated 'Smac Down' movement, and also provoked their friends to fight to the other friends.

'Bad students existed because environment influenced. Imitated their friends or imitated television program.' Said Teacher in Manokwari.

Although $84 \%$ of teacher said students were never bring sharp stuffs which is not necessary in school, but there was student who brought like sensor chain, iron, knife, razor blade, and wire to school $(26 \%)$.

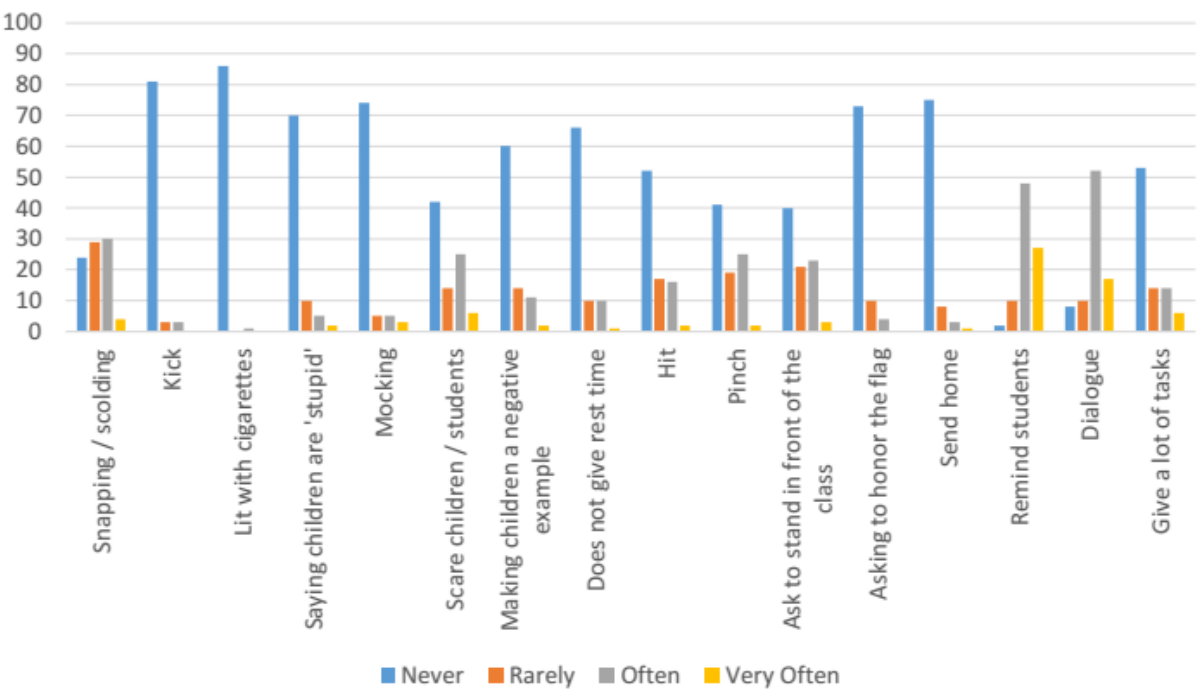

Figure 5. Kinds of punishments which given by the teachers to the students.

Explanation:

Never: 0

Rarely: $1-2$ times in a month 
Often: $1-2$ times in a week

Very Often: everydayi $/ 3-6$ times in a week

Almost $60 \%$ of teachers admitted that if did not do punishment in class, they only used to warn or remind the students, for example teachers persuaded the students to make an agreement in class and persuaded them to say magic word to be ready for study. And when both ways did not work then the teacher will yelled to them $(39 \%)$, pinched $(31 \%)$ or asked the students to stand in front of the class $(29 \%)$ a warn for the students who came late $(87 \%)$, being warned $(37 \%)$ for example their point will be cut, or will stay in their grade, and beaten $(20 \%)$ when they still do the same things.

'We used an approach to the students we can't beat the students because the parents will angry. But when the teacher told the parents about their children misbehave, they only siad my children behave was only like that...' there was no intention to change their children behavior. It was difficult for us when everything came to the teachers. 'Said teacher in Manokwari

'Beside the students being warned and adviced, but there should be a punishment to make the students realize. When the students did not care about an advice, then itold them to stand in ftont of the class or i pinched them. 'Said teacher in Biak

'I gave an advice first then if there was no change then beaten. If not, they will be more overreact.' Said Teacher in Jayawijaya

'...being warned, when they won't listen then being yelled, and when all did not work on them then they will be beaten by ruler.' Said teacher in Mimika

90

80

70

60

50

40

30

20

10

0

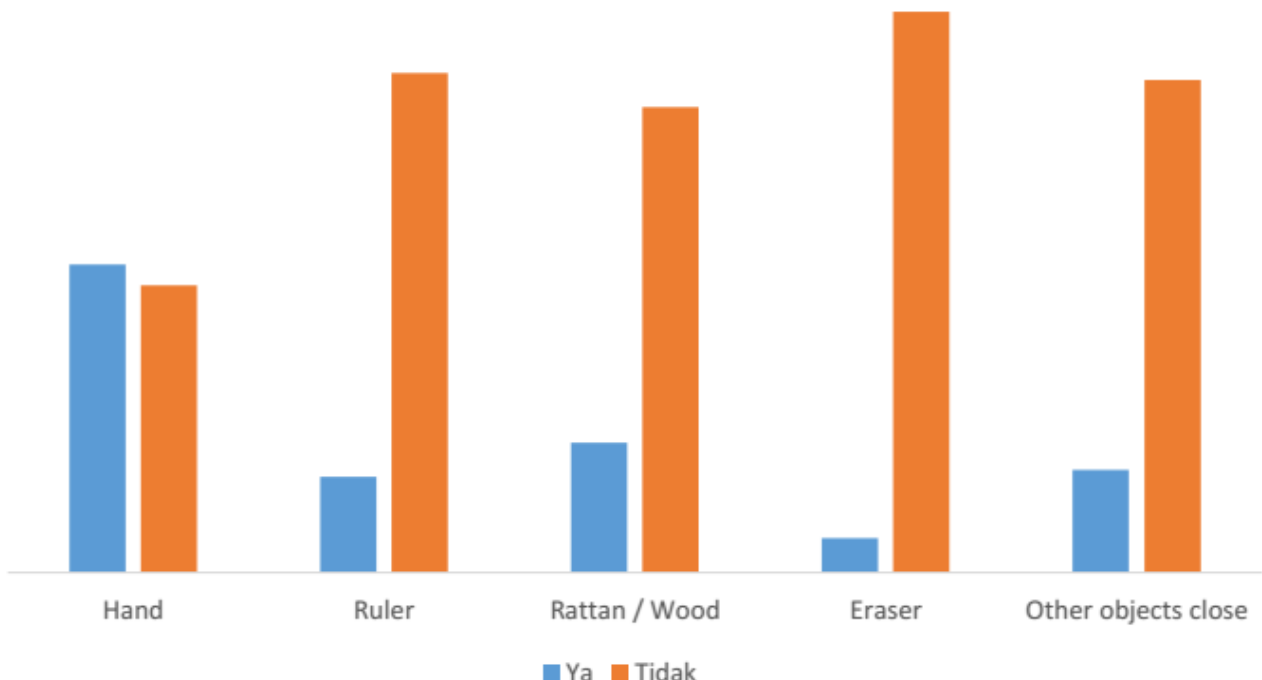

Figure 6. the tools that used in students' punishment

Teachers usually punished the students using hands (52\%). Or using bamboo/wood (22\%) .and the other tools that often used by teachers to punish their students was broom, pen/board marker, and chalk (17\%). 


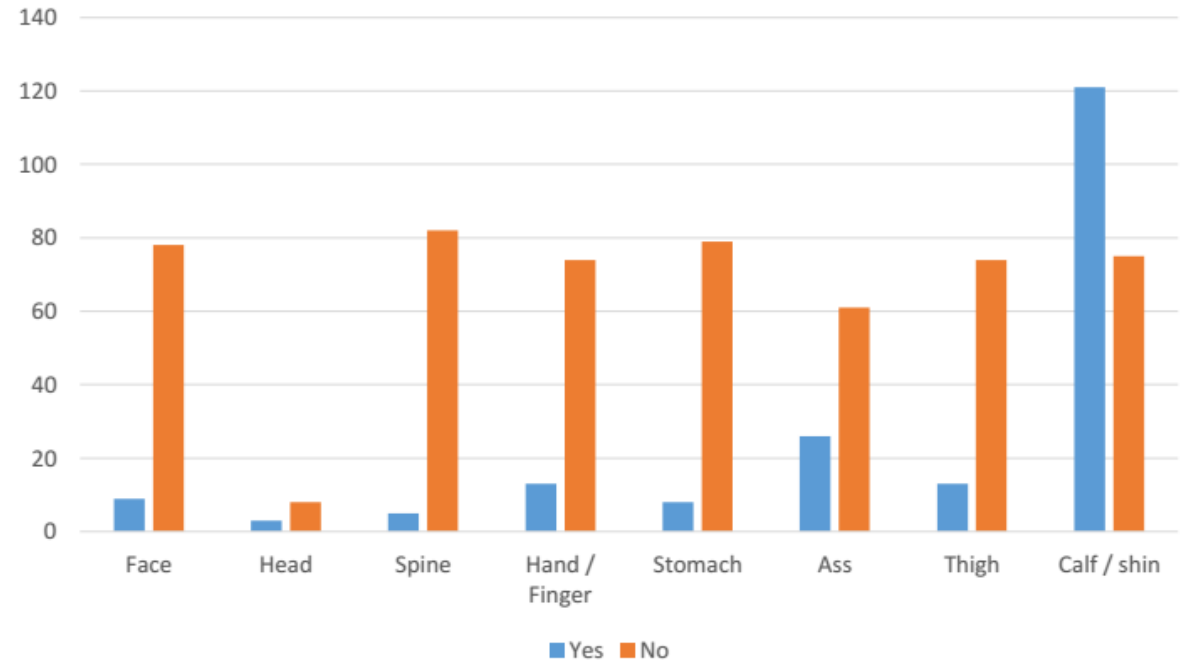

Figure 7. A part of body that became teacher's object in punishment

The $30 \%$ of teachers hitted the students on their bottom. The other part of body was became the object was hand/figger (15\%), and also legs or calf $(15 \%)$

'I used to hit on the bottom because it was not too danger. And i hitted in slowly with a small stick.' Said teacher in Jayawijaya

'If their nails were long then $i$ hitted on their finggers. 'Said teacher in Manokwari '...They'd like to fight so $i$ hitted their legs with bamboo. 'Said teacher in Mimika

80

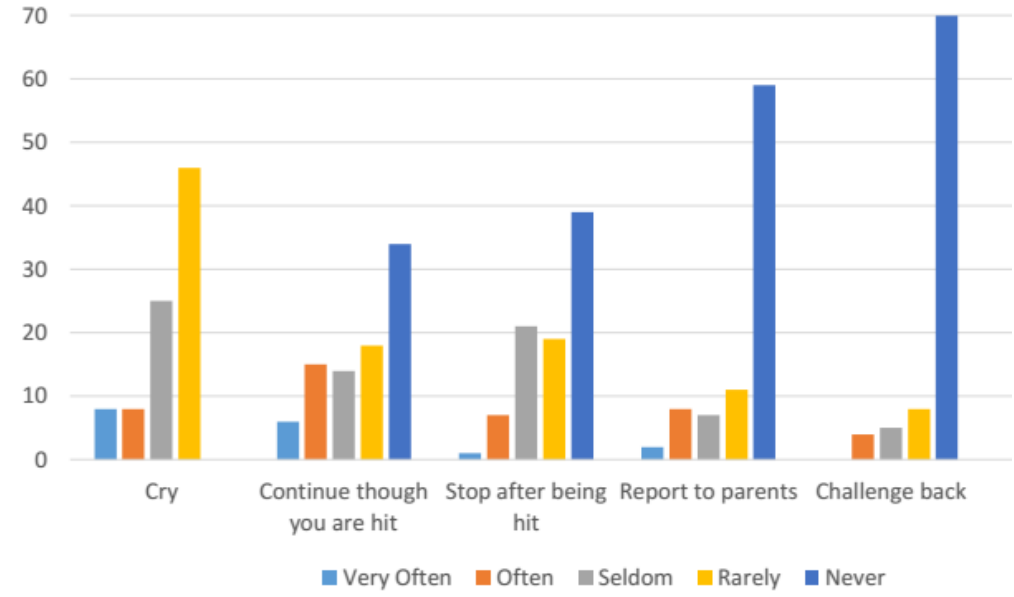

Figure 8. Students' reaction when being punished by the teachers

According to the teachers, students who got punishment did not cry (52\%) because they scared being bully and considered as cry baby by their friends. After that the students started to stop their misbehave (39\%), but it was only for a while because after that they will do it again $(45 \%)$ 
'It was only one or two students who understood of they were wrong after being punished by me and the others only considered as a nomal things.' Said teacher in Manokwari

'It was only stop when $i$ hitted them, after that they will do it again. Silent when teacher exist in the class but when the teacher left the class for a minute they will started the noise again.' Said teacher in Biak

'After being warned the students will behave better. But it was only for a minute, after that they will do it again.' Said teacher is Mimika

There was a student who changed after got punishment. And there was also did noy care.' Said teacher in Jayawijaya

There were many of Bullying cases which was happening in school. Like senior students who distrubed the junior students and make them cried, the students who has big physic distrubed the students who has small physic, insulting on the students who has disability, scractched the wall with insulting word to the other students. If this thing happened, the teacher will warned the person who did that.

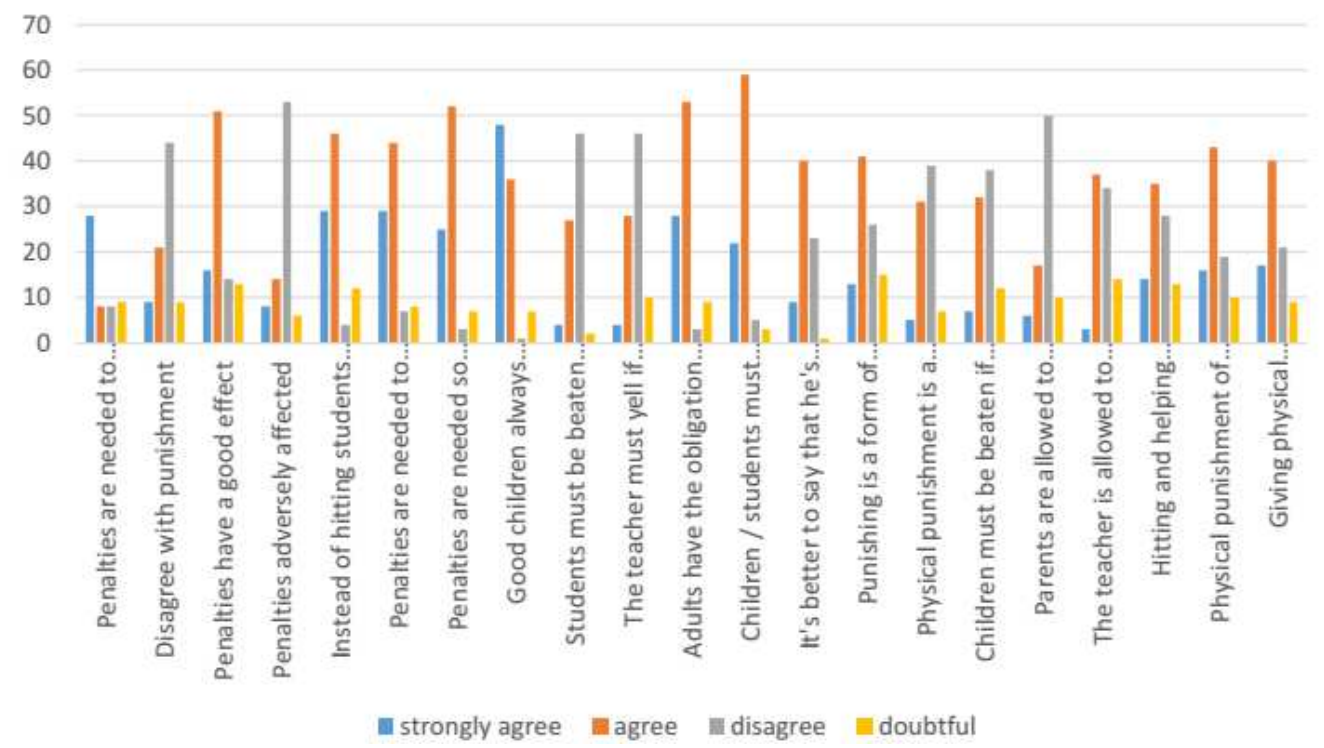

Figure 9. Teachers' opinions about punishment

Teachers agreed that students who did not obey should be punished because they believed it would bring a good impact (77\%), punishment was needed to discipline the students (80\%). It was needed in order to make the students learnt from the mistakes (59\%), and punishment become a symbol of care to the children (62\%). Adult has an obligation to discipline children/students (93\%).

'The naughty students should be hitted by affection, should be hitted by heart for a good intention, $i$ hitted them because $i$ cared with their future. In order to make them to be a good children.' Said teacher in Manokwari

'i punished them so they will understand about disciplinary. I was sad to punish them but the punishment was good to make them discipline.' Said teacher in Manokwari 'The punishment has benefit for the students. The punishment was necessary in order to make the students shy so they won't do wrong things.' Said teacher in Jayawijaya 
'A punishment is a care that given by teachers, because when the teacher did not care the students will not became sucsess.' Said teacher in Biak

'The punishment which given by teachers was aimed to teach the students in order to make them to be a better person, it was not to hurt them or did violence on them.' Said teacher in Mimika

Although it was mostly used to discipline the students. Teachers should realized that the physic punishment is danger for children (68\%). And in order to ban the use of physic punishment in school, teachers think that it was necessary to teach them alternative way to discipline the students $(94 \%)$

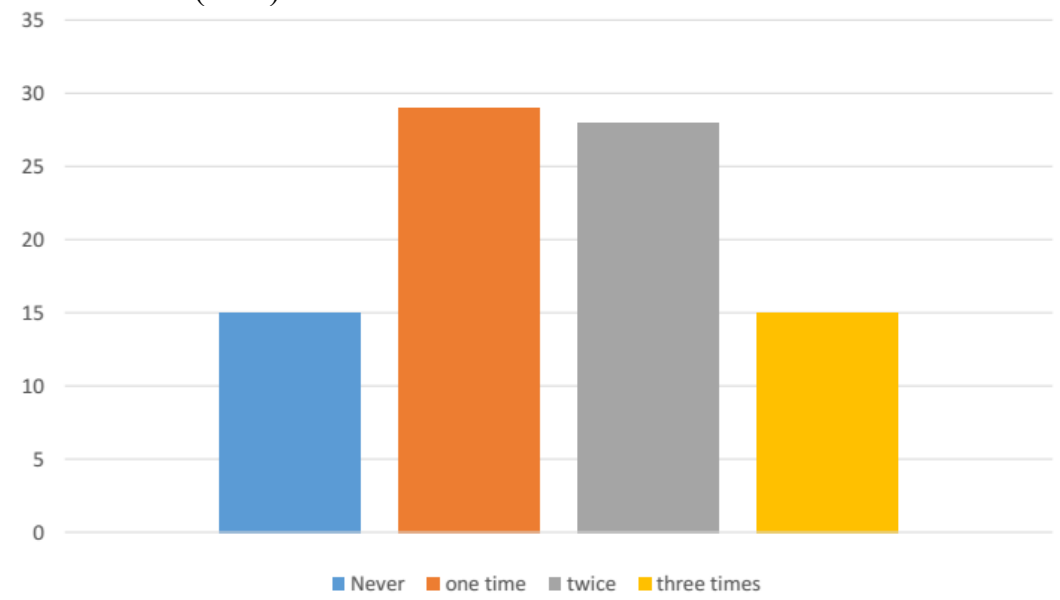

Figure 10. Routine meetings between teachers and parents

In a year teachers met to parents to discuss about behavior ur or study progress in one time $(33 \%)$, two times (32\%), three times (17\%). Even there was some teachers who never did (17\%). Generaly the meetings with students' parents held in same moment with receiving students' reports.

Student

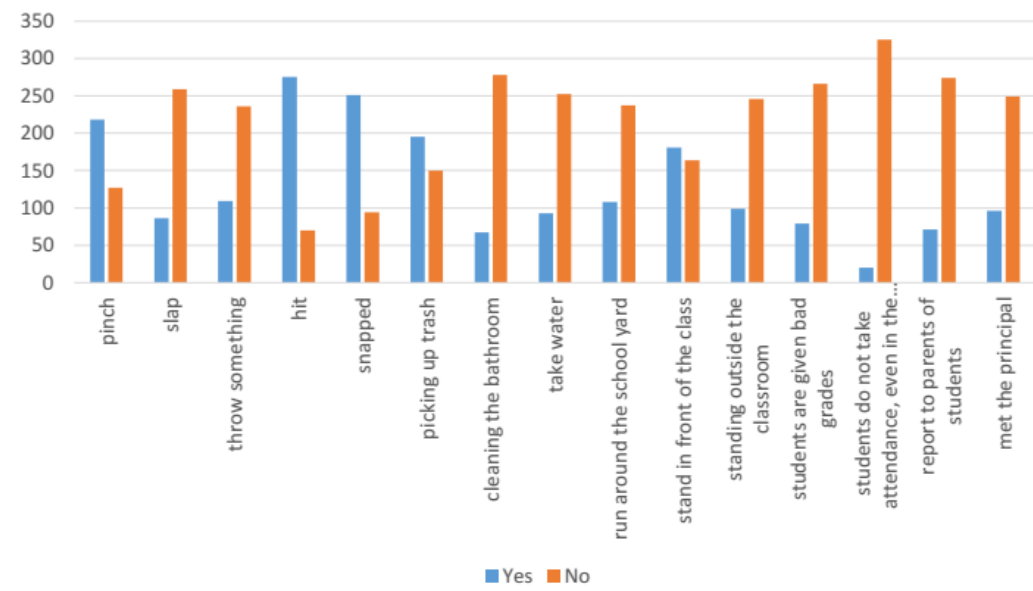

Figure 11. What kinds of punishment that used to give to the students when they did mastakes? 
The kinds of punishments which very often given by the teachers to the students was beating $(79,7 \%)$, teachers yelled/angry $(72,7 \%)$, and pinched $(63,2 \%)$.

'I learnt.... but in writing $i$ still have some mistakes. Teachers beated me.' Said student in Manokwari

'When we were writing slowly then our hands got beaten.' Said student in Mimika 'If we did not bring book, our legs got beaten. If did not bring pencils, our hands got beaten.' Said student in Jayawijaya

'If the children made some noised, teacher was took a broom then hit the table while yelled.' Said student in Mimika.

'Our teachers are good. They did not use to hit us, when we were naughty they just getting angry to us. 'Said student in Biak.

'I can't read well. Teachers pinched my ears.' Said student in Biak

'I got slaped when $i$ was wrong in reading. 'Said student in Jayawijaya

'If we answered wrong, teacher yelled: Stupid!.' Said student in manokwari

300

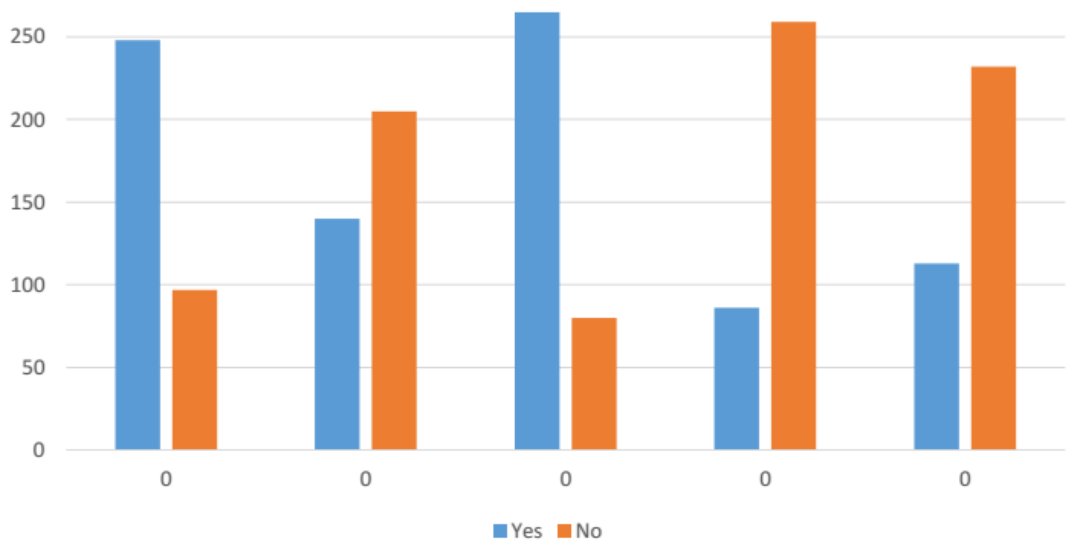

Figure 12. what kind of tools that used in punishing the students?

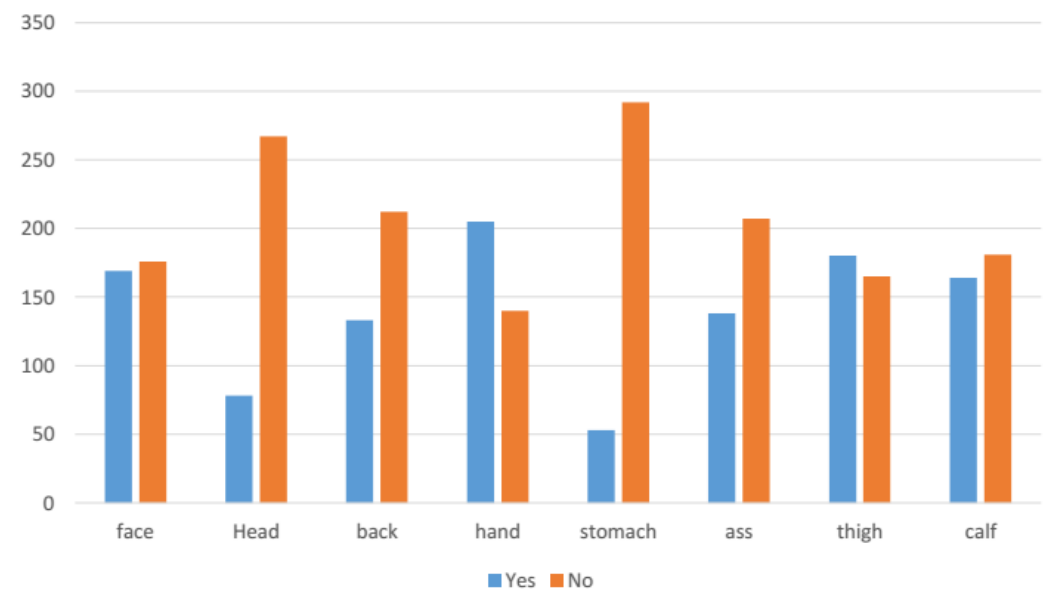

Figure 13. Which part of body that used to be an object by teachers in punishing students? 
According to the data on figure 2 and figure 3, teachers often used wood/bamboo (76,8\%), by hands $(71,8 \%)$, with rulers $(40,5 \%)$ in punishing the students. The part of body which used to be an object were hands $(59,4 \%)$, legs $(52,2 \%)$, and face- pinched on cheeks, ears, or hitted on their head $(50 \%)$.

'...the one who have dirty nails, teacher hitted on their fingers with bamboo.

' Said student in Manokwari

'I was not good in reading. Teacher hitted my head.' Said student in Biak

$41.4 \%$ of students who said that they were sad when being punished by the teachers and. $24.3 \%$ of students who considered the punishment is normal.

'I felt sad and my body was pain.... $i$ want to cry but $i$ was shy.' Said student in Manokwari

The students who considered the punisment is normal because they used to being punished so they already familiar or being forced by gulity feeling.

'It was familiar for me because $i$ usually get punishments.. 'Said student in Manokwari

'I did not feel angry because $i$ knew that $i$ was wrong.' Said student in Jayawijaya

$23.4 \%$ of students who said that they never know how the feeling being punished because they admitted that they are good students and never get punishment from the teachers

'I was an obedient student and always listen to the teachers so $i$ never get any punishment.' Said student in Manokwari

'Because $i$ was never being naughty.' Said student in Mimika

300

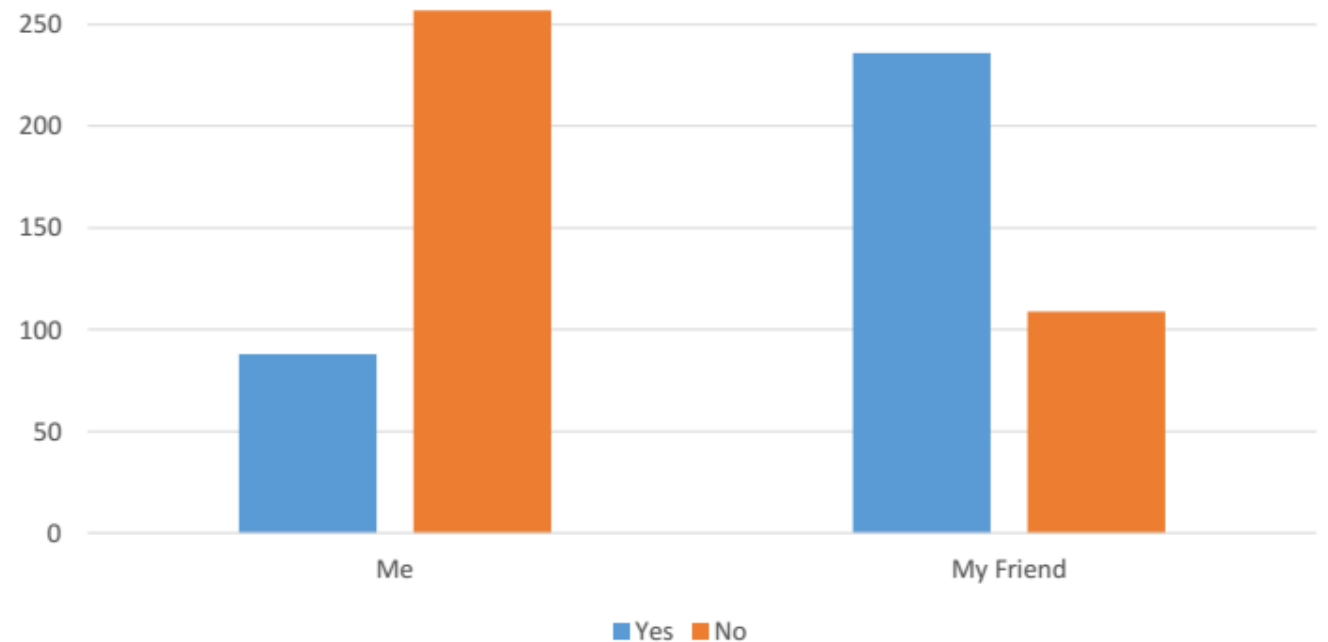

Figure 14. Does the students skip the class because worry of being punished by teachers?

$74.5 \%$ of students who followed the interview said that they never skipped from the class, but there were a lot of their friends who skipped from the class $(68,4 \%)$ who skipped from the class because they were worry to got punishment from the teachers. 
'My friend.... teachers used to hit them because they cant write a,b,c... so they were scared to go to school. ' Said student in Manokwari

'He scared when being asked to read. Because if he cant do that, he got punished by teacher.' Said student in Biak

'...because he was very often got angry from teachers.' Said student in Jayawijaya 'My friend skipped the class because he forgot to do the homework. 'Said student in Mimika

Beside the reason was the worry being punished, there were some students who skipped the class because of hungry.

'Students skipped from school because hungry. They back to home in rest time but they were not back to school. And tomorrow they were worry to go to school because worried of being punished.' Said student in Manokwari

'They skipped the class because of hungry.' Said student in Jayawijaya

$54.4 \%$ of students said if they become a teacher, they will punish the students who dont obey to their teachers.

'I used to being hitted when $i$ was naughty. So i also will punish the students who is naughty.' Said student in Manokwari

'...Just to pinch them... so it will not too hurt. 'Said student in Manokwari

'If wrong then they should get punishment. So they wont do that again... 'Student in biak

'...in order to make the students study more.' Said student in Mimika

$45.5 \%$ of students said that they will never hit the students when they become a teacher in future.

'My hands are heavy, i can't beat them. I want they study well.. and not worry. 'Said student in Manokeari

'Because if care then dont beat them... 'Said student in Biak

'I did not want to beat them. My heart is sad when i see children cry.' Said student in Jayawijaya

'I am worried that parents will come to school and angry. 'Said student in Mimika

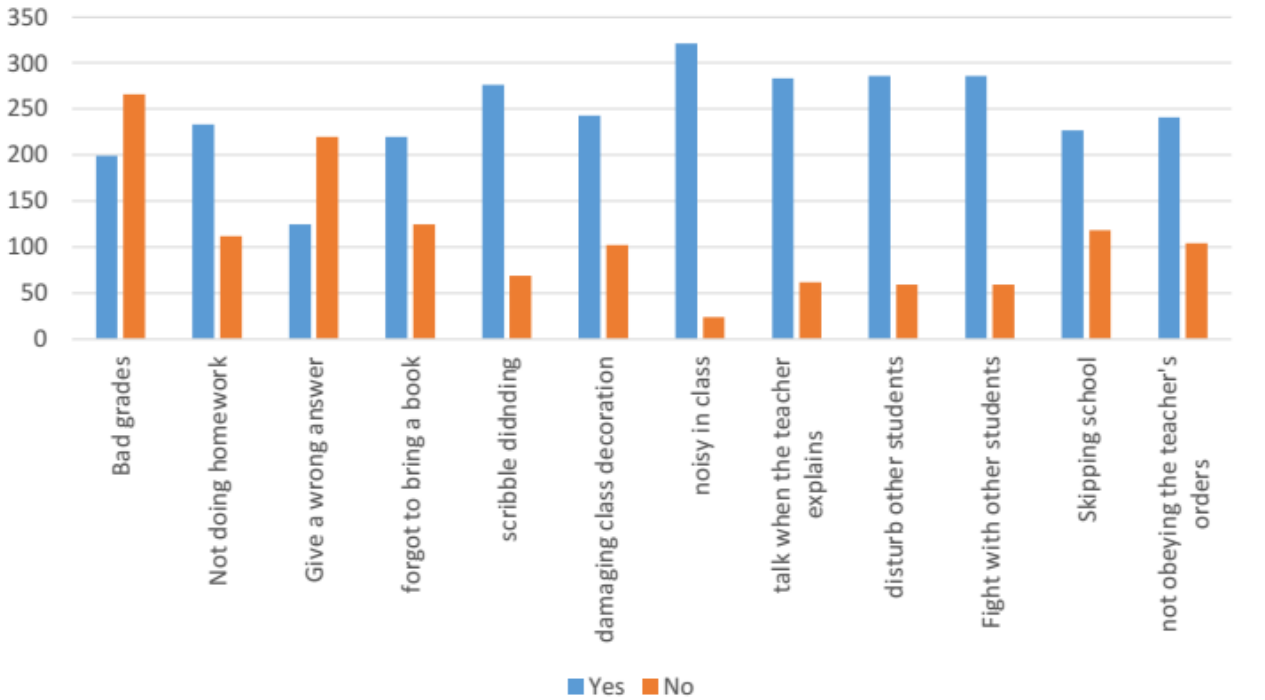

Figure 15. what kind of things that you or your friends ever done and make the teachers angry? 
Students' behavior which make the teachers angry is make some noise in class (93\%), distubed the other students $(83 \%)$, fight with the other students $(83 \%)$, and were talking while teachers gave explanation in front of the class $(82 \%)$.

'Students were very noisy... then being hitted with ruler on their mouth. 'Said student in Mimika

'My friend took my bag away. I hitted them. Teacher slapped me.' Said student in Biak

'My friends distrubed me and I insulted him, my teacher hitted them with bamboo. And i should eat chili.' Said student in Manokwari

'When i throw the rubish everywhere then the teacher punished me by eat the paper. When i tear books to make some airplane papers, teacher punished me to bite the book. 'Said student in Mimika.

'When i did mistake, teacher gave me a wood, and we should hit ourselves.' Said student in Jayawijaya.

'When there ones broken the rule, teacher asked the chairman to hit us. 'Said student in Mimika

$76 \%$ of students admitted that they ever get some compliments because having a good attitude.

'Teacher gave me a thumb up when i could write the letter neatly... 'Said student in Manokwari

'Teacher said that $i$ was clever because my assignment was correct.' Said student in Biak

'When i read fluently, teacher said $i$ was good. Then they gave thump up to me. I was very happy. 'Said student in Jayawijaya.

'Teacher said $i$ was diligent because always did the assignments. 'Said student in Mimika

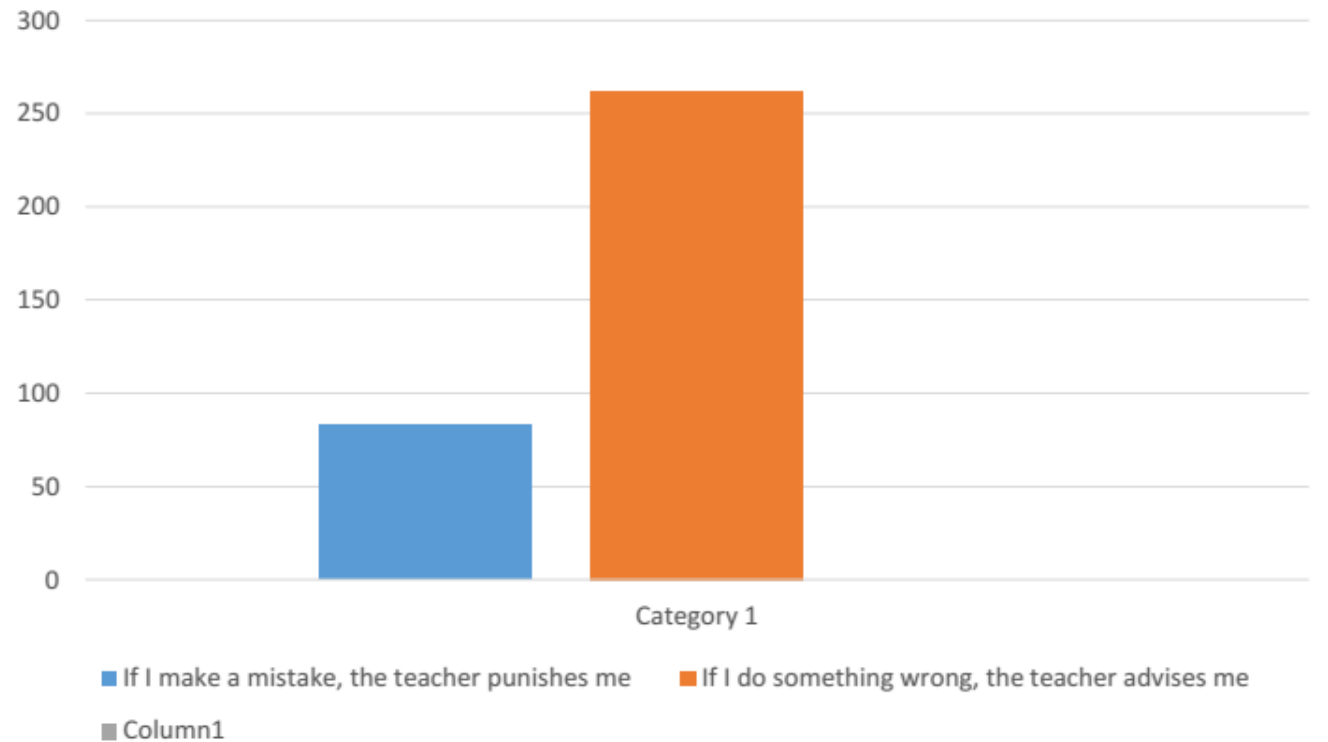

Column1

Figure 16. When you did mistake, which one you choose? 
$75.9 \%$ of students rather chose being adviced when did mistakes because it will not make them hurt, scare, and shy.

'It is better to say: dont do that again... dont hot... it is pain... 'Said student in Manokwari

'So $i$ will be smart not scare. 'Said student in Jayawijaya 'Angry is not good. 'Said student in Mimika

'Because of being hitted, it means angry.. and being adviced means care.' Said student in Biak.

Meanwhile $74,1 \%$ chose punishment when they did mistake because they were deserve to get it. Beside the students considered punishment as teachers' attention and care for their future.

'Because $i$ was naughty so it was fine to get punishment.' Student in Jayawijaya '... because we already did some mistakes... 'Said student in Biak

'Teachers punished us because they were care. So we are going to be smart and upgrade our grade. 'Said student in Manokwari

'When teacher hitted us it did meant that they are bad but they care us. They want us to be smart. 'Said student in Mimika

\section{Conclusion and Suggestion}

Discipline practice should conducted involving all of member in shcool like teachers, educators, and students. Teachers' attitude and behavior are very important for desire and spirit of students' learning. The punishment was used by the teachers may become bad memory and bring bad impact in teaching and learning process. The result of study showed that teachers still wrong in interpreting discipline and they considered as a punishment. Teacher still did not understand how to discipline their students in a right way. All this time teachers responded students misbehave in hard way, embarrassing, and insulting. Teachers continuesly got angry /punished the students even to the small mistakes. Even teacher were easy to become angry to the students who in the study process still less than the other students (for example still not fluent in reading). To become angry and did punishments to the students continuesly made the students familiar and will never listen or obey the teachers even they became insensitve from the punishmenst. Discipline practice will only bring temporary obedience which born from fear, it was not coming from awareness and could change their attitude. Then the students who often getting punishments will acted agressively and hostile. And to respond on that, one of the ways to build discipline value without showing violence or punishment to the students is using positive discipline. This method better to not only introduce to the teachers but also the parents.

\section{References}

[1] Antarini Pratiwi Arna, Etc (2005): Kekerasan terhadap Anak di Mata Anak Indonesia: Hasil Konsultasi Anak tentang Kekerasan Terhadap Anak di 18 Propinsi dan Nasional. Jakarta: Ministry of Women's Empowerment (KPP).

[2] BPS (2011) Multiple Indicators Cluster Studi (MICS) di Papua dan Papua Barat

[3] UN Joint Program (2011): KAP Study tentang Kekerasan terhadap Perempuan dan Anak di Provinsi Papua 